\title{
Price Formation of Coffee Beans: New Evidence from the Japanese Market
}

\author{
Tadahiro Nakajima ${ }^{1}$ \\ ${ }^{1}$ Graduate School of Economics, Kobe University, Kobe, Japan \\ Correspondence: Tadahiro Nakajima, Graduate School of Economics, Kobe University, 2-1 Rokkodai-cho Nada-ku, \\ Kobe, Hyogo Prefecture, 657-8501, Japan. E-mail: nakajima.tadahiro@diamond.kobe-u.ac.jp
}

Received: May 19, 2014

Accepted: June 8, 2014

Online Published: June 24, 2014

doi:10.5430/rwe.v5n2p23

URL: http://dx.doi.org/10.5430/rwe.v5n2p23

\begin{abstract}
This study tested for Granger causality among international market prices of coffee beans, import prices, retail prices, and other luxury beverage retail prices in Japan. Granger causality was found from the international market price series to the import price series. This indicates that Japan procures coffee beans at a price consistent with the international market price. Granger causality between import prices and retail prices was not observed. This reveals that the import price is not easily passed through to the retail price. In the retail market, Granger causality was detected from instant coffee prices to both coffee bean prices and green tea prices. Green tea prices were observed to Granger-cause black tea prices. This demonstrates that instant coffee is the only substitute good for coffee beans and the price maker in the luxury beverage market.
\end{abstract}

Keywords: coffee beans, causality, international market price, import price, retail price

\section{Introduction}

Coffee is one of the most commonly consumed luxury products in many countries around the world. People drink coffee in various settings: at home, in restaurants, and at the workplace. Moreover, coffeehouse chains have numerous stores all over the world. Because coffee is a luxury beverage, its consumption and/or price tend to be influenced by economic trends. A cup of coffee is prepared by brewing ground coffee beans or by mixing instant coffee powder in hot water. We can assume that instant coffee is the leading substitute good for coffee beans among consumers; although, other luxury beverages could also be substitutes.

Futures contracts for coffee beans are traded on the IntercontinentalExchange Futures U.S. (ICE US), the London International Financial Futures and Options Exchange (LIFFE), and the Tokyo Grain Exchange (TGE). Coffee beans are a commodity typical of those traded in the futures markets, comparable to corn, soybeans, and wheat. In order to hedge price-fluctuation risks, to derive fair prices, and to operate funds as a new class of assets, both expectations and concerns about commodity markets have been increasing. The coffee market is also subject to this tendency. The trading volumes of Coffee $\mathrm{C}$ futures on the ICE US have been increasing. According to the market report prepared by the U.S. Commodity Futures Trading Commission (CFTC), the open interest in 2007 (8.2 million contracts of 37,500 pounds) was 3.4 times that in 2000 (2.4 million contracts of 37,500 pounds). The coffee market has seen the participation of not only commercial traders, but also many non-commercial traders. Therefore, the prices can be expected to have assimilated different kinds of information pertaining to coffee beans. In 2007, the long and short positions of commercial traders were $48 \%$ and $62 \%$ of total open interest, respectively.

All coffee plants are grown between the Tropics of Cancer and Capricorn, an area called the Coffee Bean Belt. Brazil is the world leader in the production of coffee seeds, followed by Vietnam and Indonesia. These three countries produce more than $50 \%$ of the world's green coffee, according to a survey conducted by the International Coffee Organization (ICO). On the other hand, the majority of coffee beans are consumed in developed countries. Consumption in the European Union, the United States, and Japan accounts for more than half of the world's consumption. Coffee beans are primary goods with the second largest trade scale after crude oil, because non-producing countries are the main consumers and coffee beans form a high-value agricultural product.

Krivonos (2004) studies the speed of price transmission between producers and international prices in more than ten coffee exporting countries. Mehta and Chavas (2008) examine the impact of termination of the export quota system 
on the relationship between producer prices in exporting countries, international prices, and retail prices in importing countries. Delille (2008) analyzes the relationship between coffee's world market price and its Belgian retail price. Gómez and Koerner (2009) and Lee and Gómez (2013) investigate the price transmission from international to retail prices of coffee in France, Germany, and the United States. Maurice and Davis (2011) empirically analyzes the patterns and causes of volatility for coffee and cocoa. Moreover, it examines the relationship among coffee, cocoa, and oil prices. Li and Saghaian (2013a) investigates the relationship between the world price of coffee beans and the producer price in Vietnam by applying a vector error correction model. Li and Saghaian (2013b) employs an Error Correction Model in order to examine the market integration and price transmission between the world and the grower price in Columbia and Vietnam. However, no paper has investigated the relationship among international market prices, import prices, retail prices, and retail prices of the substitute. Furthermore, there is no paper that has examined the formation of coffee prices in Japan, which is the fourth largest coffee consuming country in the world followed by the United States, Brazil, and Germany.

This study analyzes the transmission of information from the international market price of coffee beans to the imported price, from the imported price to the retail price, and between the retail price and the price of substitute goods. Therefore, the study examines the coffee beans' price formation in Japan, which is one of the largest coffee consuming countries.

The remainder of this paper is organized as follows. Section 2 explains the methodology applied, Section 3 describes the data analyzed, Section 4 presents the empirical results, and Section 5 provides the summary and conclusions.

\section{Method}

This study analyzes the price formation of coffee beans, in three stages. In the first stage, this paper tests for Granger causality between the international market price series and the import price series in Japan. The result should reveal whether the Japanese procurement price is consistent with the international market price, and whether the purchases of a large consuming country affect the international market. In the second stage, the Granger causality between the import price and retail price is examined. From this result, we can observe whether the import price is easily passed on to the retail price in the coffee market. Conversely, it should also become clear whether the retail price affects the procurement of coffee beans. In the final stage, this paper investigates Granger causality among the retail prices of luxury beverages, including coffee beans, instant coffee, black tea, and green tea. The results of this analysis should clarify which goods are substitutes for coffee beans. Simultaneously, we may confirm what the price maker is for luxury beverages.

This paper applies the lag-augmented vector autoregression (LA-VAR) technique developed by Toda and Yamamoto (1995) to test for Granger causality. The LA-VAR approach allows testing for Granger causality among time series variables in levels, without taking their integration and cointegration properties into consideration. The method proceeds, briefly, as follows.

Assume that the following equation generates $\left\{z_{t}\right\}$, the $n$-dimensional vector constituting the level of the variables in the study:

$$
z_{t}=g_{o}+g_{1} t+J_{1} z_{t-1}+J_{2} z_{t-2}+\cdots+J_{l} z_{t-l}+\varepsilon_{t}, \quad t=1,2, \ldots, T,
$$

where $t$ is the time trend; $l$ is the lag length; $g_{o}, g_{1}, J_{1}, J_{2}, \ldots, J_{l}$ are vectors or matrices of coefficients; and $\varepsilon_{t}$ is an iid sequence of $n$-dimensional random vectors with zero mean and covariance matrix $\Sigma_{\varepsilon}$.

One formulates the null hypothesis that the $j$-th variable does not Granger-cause the $i$-th variable as follows:

$$
H_{0}: J_{i j}(1)=J_{i j}(2)=\cdots=J_{i j}(l)=0,
$$

where $J_{i j}(h)$ is the $(i, j)$ element of the matrix $J_{h}(h=1,2, \ldots, l)$. The test can be conducted with the following VAR model, in level form, estimated by ordinary least squares (OLS):

$$
z_{t}=\hat{\gamma}_{0}+\hat{\gamma}_{1} t+\hat{J}_{1} z_{t-1}+\hat{J}_{2} z_{t-2}+\cdots+\hat{J}_{m} z_{t-m}+\hat{\varepsilon}_{t}
$$

where the circumflex $\left({ }^{-}\right)$indicates OLS estimation and $m=l+d_{\max }$ represents the true lag length $l$ augmented by a suspected maximum integration order, $d_{\max }\left(l \geq d_{\max }\right)$. Considering that the true value of $J_{1}$, $J_{2}, \ldots, J_{m}$ is zero, these parameters are not included in restriction (2). Toda and Yamamoto (1995) establish that the Wald statistic asymptotically has a chi-square distribution with degrees of freedom equal to the number of excluded 
lagged variables regardless of the integration order of the process or existence of a cointegrating relation.

\section{Data}

The tests in this study use monthly data from the beginning of 2000 until the end of 2007. This study uses ICO indicator prices as the international market prices of green coffee. These prices are expressed in US cents per pound. The datasets are obtained from the ICO website (http://www.ico.org/index.asp).

The prices of imported coffee beans are calculated as the quotient of the value and volume imported, using data obtained from the website of the Japanese Ministry of Finance's Custom and Tariff Bureau of the Japanese Government (http://www.customs.go.jp/english/index.htm). These prices are expressed in yen per kilogram. This paper uses the Tokyo retail prices of coffee beans, instant coffee, black tea, and green tea as the representative prices of luxury beverages. These datasets are obtained from the website of the Ministry of Internal Affairs and Communications' Statistics Bureau (http://www.stat.go.jp/english/index.htm). The prices of coffee beans, instant coffee, black tea, and green tea are expressed in yen per 200 grams, yen per 100 grams, yen per 25 tea bags, and yen per 100 grams, respectively. All these variables are converted from yen-denominated values to US dollar-denominated values using the monthly average Telegraphic Transfer Middle Rate.

Figure 1 provides the time plots of the natural logarithm of the ICO indicator price, the price of imported coffee beans, and the retail price of coffee beans. Figure 2 illustrates the trend of the retail prices for coffee beans, instant coffee, black tea, and green tea. Table 1 reports the results obtained from the augmented Dickey-Fuller (ADF) test, which was applied to the natural logarithm and the first difference of the natural logarithm. Appropriate lag orders are determined by minimizing the Schwarz information criterion (SIC). Although the price of imported coffee beans and the retail prices of instant coffee and green tea trend toward an acceptance of the unit root, the hypothesis that the ICO indicator prices and the retail prices of coffee beans and black tea have a unit root cannot be accepted. The LA-VAR technique is effective in testing without bias for Granger causality among these variables, which may differ from each other in their integrated order.

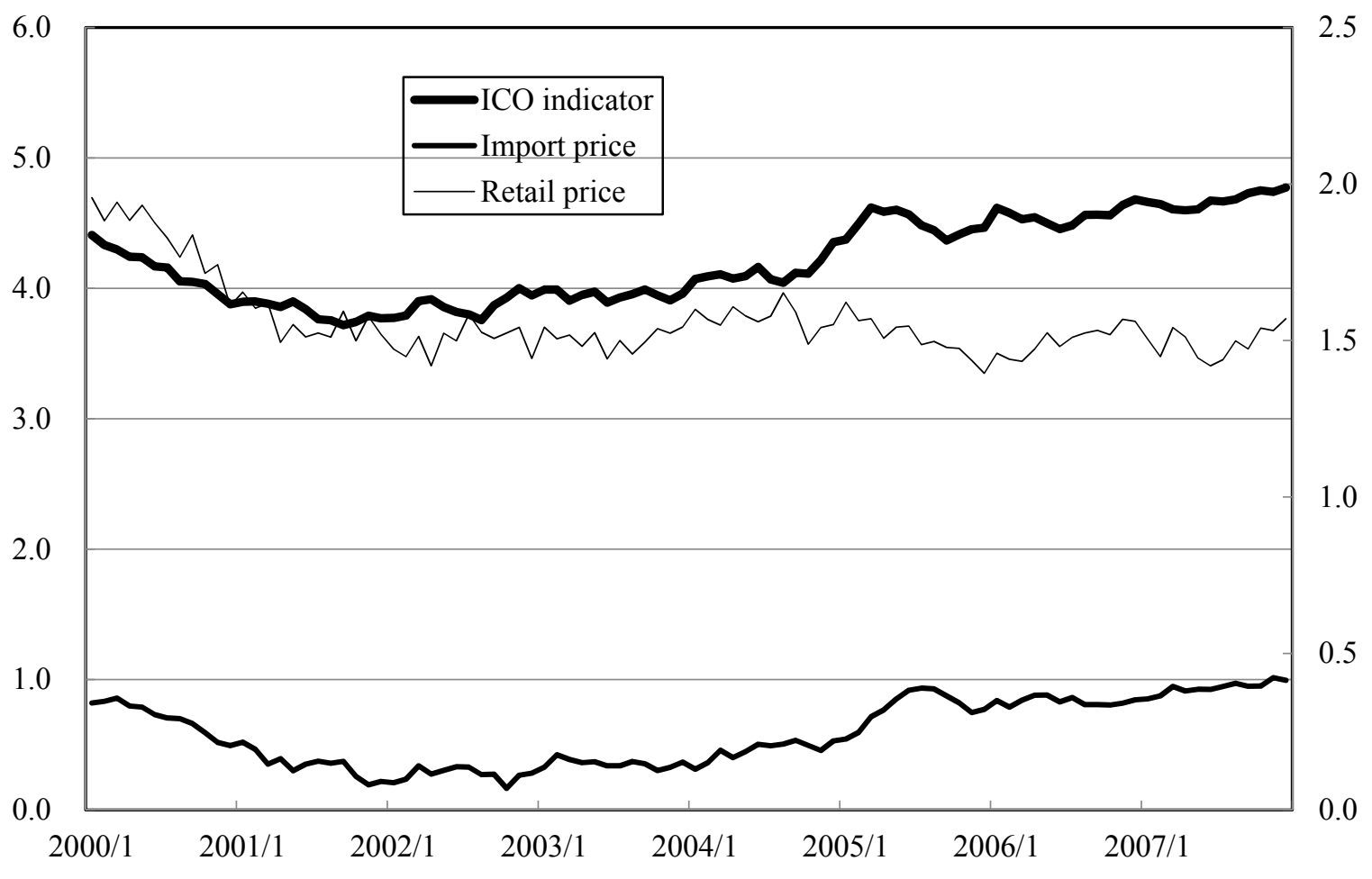

Figure 1. Prices of coffee beans 


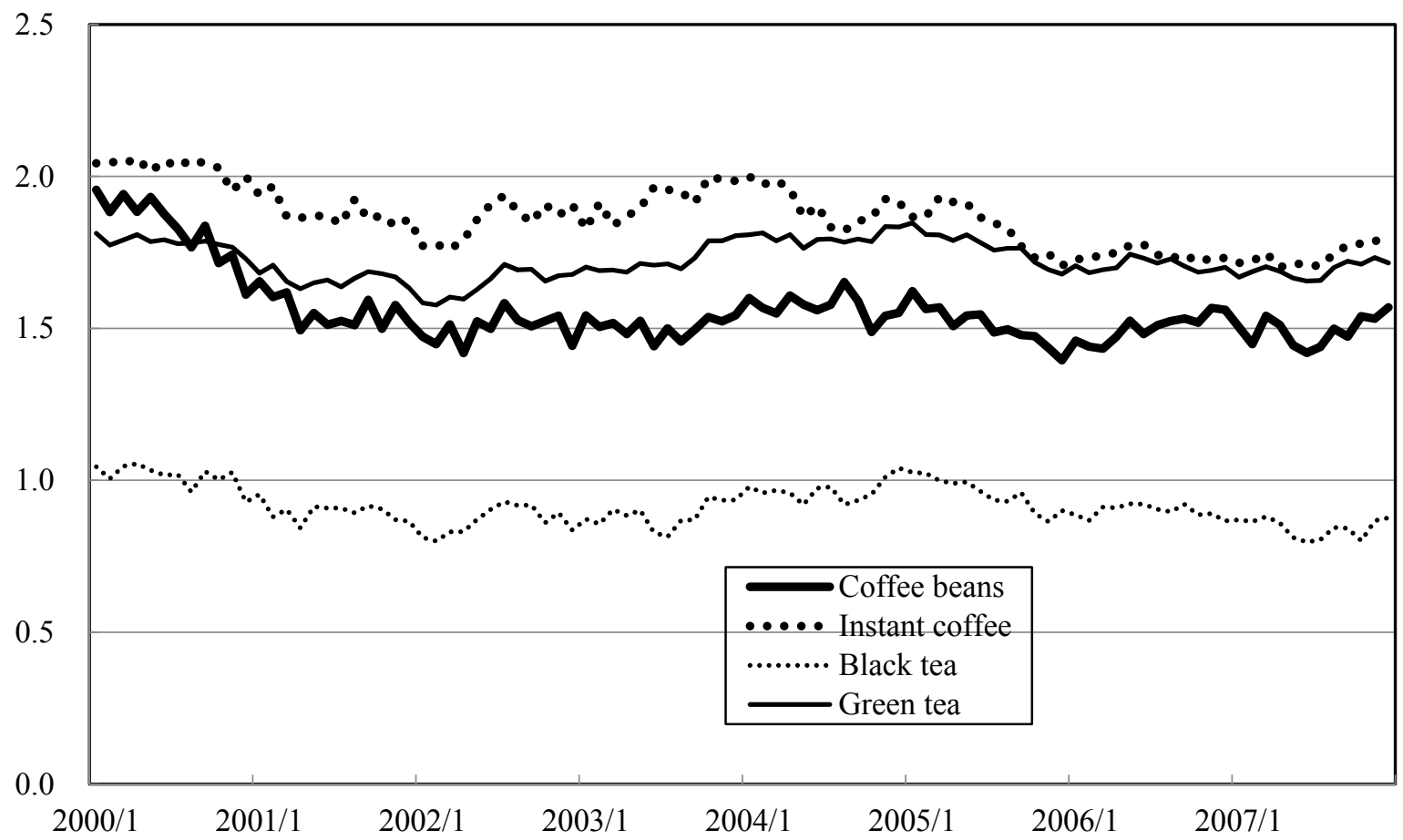

Figure 2. Retail prices of luxury beverages

Table 1. Augmented Dickey-Fuller unit root tests results

\begin{tabular}{llrrrrrr}
\hline & & \multicolumn{3}{c}{ Natural logarithm of levels } & \multicolumn{3}{c}{ First differences of natural logarithm } \\
\cline { 2 - 7 } & & None & Constant & Constant + trend & None & Constant & Constant + trend \\
\hline ICO & No. of lags & 0 & 0 & 0 & 0 & 0 & 0 \\
& t-Statistics & 0.651 & -0.054 & $-3.459^{*}$ & $-8.116^{*}$ & $-8.121^{*}$ & $-8.461^{*}$ \\
& Probabilities & 0.855 & 0.950 & 0.050 & 0.000 & 0.000 & 0.000 \\
\hline \multirow{2}{*}{$I M$} & No. of lags & 0 & 0 & 0 & 0 & 0 & 0 \\
& t-Statistics & 0.118 & -0.516 & -2.434 & $-9.308^{*}$ & $-9.267^{*}$ & $-9.788^{*}$ \\
& Probabilities & 0.718 & 0.882 & 0.360 & 0.000 & 0.000 & 0.000 \\
\hline$R C$ & No. of lags & 1 & 1 & 1 & 0 & 0 & 0 \\
& t-Statistics & -1.344 & $-3.272^{*}$ & -2.508 & $-16.593^{*}$ & $-16.651^{*}$ & $-17.048^{*}$ \\
& Probabilities & 0.165 & 0.019 & 0.324 & 0.000 & 0.000 & 0.000 \\
\hline$R I$ & No. of lags & 1 & 1 & 2 & 0 & 0 & 0 \\
& t-Statistics & -1.069 & -1.866 & -2.609 & $-13.377^{*}$ & $-13.407^{*}$ & $-13.374^{*}$ \\
& Probabilities & 0.256 & 0.347 & 0.278 & 0.000 & 0.000 & 0.000 \\
\hline$R T$ & No. of lags & 1 & 0 & 0 & 0 & 0 & 0 \\
& t-Statistics & -0.710 & $-3.077^{*}$ & -3.099 & $-13.174^{*}$ & $-13.136^{*}$ & $-13.083^{*}$ \\
& Probabilities & 0.407 & 0.032 & 0.113 & 0.000 & 0.000 & 0.000 \\
\hline$R G$ & No. of lags & 0 & 0 & 0 & 0 & 0 & 0 \\
& t-Statistics & -0.491 & -2.206 & -2.214 & $-9.983^{*}$ & $-9.935^{*}$ & $-9.886^{*}$ \\
& Probabilities & 0.501 & 0.206 & 0.476 & 0.000 & 0.000 & 0.000 \\
\hline
\end{tabular}

Note: ${ }^{*}$ Unit-root hypothesis is rejected at the 5\% significance level. 


\section{Empirical Results}

4.1 Granger Causality between the ICO Index Price and the Imported Coffee Bean Price

Let $I C O_{t}$ and $I M_{t}$ denote the ICO index price series and the imported coffee bean price series, respectively. The appropriate lag orders are determined by minimizing the SIC to estimate the VAR model as follows:

$$
\begin{gathered}
\ln I C O_{t}=-0.093+0.001 t+1.038 \ln I C O_{t-1}-0.164 \ln I C O_{t-2}+0.154 \ln I C O_{t-3}-0.280 \ln I M_{t-1} \\
-0.005 \ln I M_{t-2}+0.150 \ln I M_{t-3} \\
\ln I M_{t}=-2.306-0.001 t+0.086 \ln I C O_{t-1}+0.210 \ln I C O_{t-2}+0.369 \ln I C O_{t-3}+0.211 \ln I M_{t-1} \\
\quad-0.005 \ln I M_{t-2}+0.076 \ln I M_{t-3}
\end{gathered}
$$

The Wald test can be conducted with the following VAR model estimated using OLS:

$$
\begin{gathered}
\ln I C O_{t}=0.555+0.002 t+1.029 \ln I C O_{t-1}-0.207 \ln I C O_{t-2}+0.297 \ln I C O_{t-3}-0.280 \ln I C O_{t-4} \\
-0.175 \ln I M_{t-1}+0.092 \ln I M_{t-2}+0.022 \ln I M_{t-3}+0.123 \ln I M_{t-4} \\
\ln I M_{t}=-2.571-0.001 t+0.101 \ln I C O_{t-1}+0.222 \ln I C O_{t-2}+0.298 \ln I C O_{t-3}+0.121 \ln I C O_{t-4} \\
+0.178 \ln I M_{t-1}-0.043 \ln I M_{t-2}+0.185 \ln I M_{t-3}-0.113 \ln I M_{t-4}
\end{gathered}
$$

The Wald test results are reported in Table 2 . With statistical significance at the $5 \%$ level, there is Granger causality from the ICO index price to the imported coffee bean price in Japan; however the import price does not influence the ICO index price.

Table 2. Results of LA-VAR tests between ICO indicator and import prices

\begin{tabular}{llrr}
\hline Dependent variables & Statistics & \multicolumn{2}{l}{ Independent variables } \\
\cline { 2 - 4 } & & $\ln (I M)$ & \\
\hline $\ln (I C O)$ & Wald statistics & $207.637^{*}$ & 1.202 \\
& Probabilities & $0.000^{*}$ & 0.753 \\
\hline $\ln (I M)$ & Wald statistics & $91.439^{*}$ & 7.122 \\
& Probabilities & $0.000^{*}$ & 0.068 \\
\hline
\end{tabular}

Note: $*$ denotes significance at the $5 \%$ level.

\subsection{Granger Causality between the Imported Coffee Bean Price and the Coffee Bean Retail Price}

Let $R C_{t}$ denote the coffee bean retail price series. Appropriate lag orders are determined by minimizing the SIC to estimate the VAR model as follows:

$$
\begin{gathered}
\ln I M_{t}=-0.197+0.001 t+0.876 \ln I M_{t-1}+0.012 \ln I M_{t-2}+0.019 \ln R C_{t-1}+0.105 \ln R C_{t-2} \\
\ln R C_{t}=0.235+0.072 \ln I M_{t-1}-0.056 \ln I M_{t-2}+0.384 \ln R C_{t-1}+0.460 \ln R C_{t-2}
\end{gathered}
$$

The Wald test can be conducted with the following VAR model estimated using OLS:

$$
\begin{aligned}
\ln I M_{t}=-0.227 & +0.002 t+0.848 \ln I M_{t-1}+0.067 \ln I M_{t-2}-0.051 \ln I M_{t-3}-0.047 \ln R C_{t-1} \\
& +0.023 \ln R C_{t-2}+0.165 \ln R C_{t-3} \\
\ln R C_{t}=0.251+ & 0.053 \ln I M_{t-1}+0.111 \ln I M_{t-2}-0.157 \ln I M_{t-3}+0.379 \ln R C_{t-1}+0.429 \ln R C_{t-2} \\
+ & 0.027 \ln R C_{t-3}
\end{aligned}
$$


The Wald test results are reported in Table 3. With statistical significance at the 5\% level, there is no Granger causality between the imported coffee bean price and the coffee bean retail price.

Table 3. Results of LA-VAR tests between the import price and retail price

\begin{tabular}{llrr}
\hline Dependent variables & Statistics & \multicolumn{2}{l}{ Independent variables } \\
\cline { 3 - 4 } & & \multicolumn{2}{c}{$\ln (R C)$} \\
\hline $\ln (I M)$ & Wald statistics & $121.317^{*}$ & 0.184 \\
& Probabilities & $0.000^{*}$ & 0.912 \\
\hline $\ln (R C)$ & Wald statistics & 2.620 & $48.847^{*}$ \\
& Probabilities & 0.270 & $0.000^{*}$
\end{tabular}

Note: * denotes significance at the $5 \%$ level.

\subsection{Granger Causality between the Retail Prices of Luxury Beverages}

Let $R I_{t}, R T_{t}$, and $R G_{t}$ denote the instant coffee retail price series, the black tea retail price series, and the green tea retail price series, respectively. Appropriate lag orders are determined by minimizing the SIC to estimate the VAR model as follows:

$$
\begin{gathered}
\ln R C_{t}=0.038+0.001 t+0.743 \ln R C_{t-1}+0.367 \ln R I_{t-1}+0.153 \ln R T_{t-1}-0.293 \ln R G_{t-1} \\
\ln R I_{t}=0.257-0.001 t+0.037 \ln R C_{t-1}+0.682 \ln R I_{t-1}-0.086 \ln R T_{t-1}+0.229 \ln R G_{t-1} \\
\quad \ln R T_{t}=-0.210-0.010 \ln R C_{t-1}+0.059 \ln R I_{t-1}+0.483 \ln R T_{t-1}+0.348 \ln R G_{t-1}
\end{gathered}
$$

$$
\ln R G_{t}=0.130+0.001 t-0.030 \ln R C_{t-1}+0.213 \ln R I_{t-1}+0.147 \ln R T_{t-1}+0.622 \ln R G_{t-1}
$$

The Wald test can be conducted with the following VAR model estimated using OLS:

$$
\begin{gathered}
\ln R C_{t}=0.155+0.001 t+0.338 \ln R C_{t-1}+0.487 \ln R C_{t-2}+0.350 \ln R I_{t-1}-0.058 \ln R I_{t-2} \\
+0.049 \ln R T_{t-1}+0.296 \ln R T_{t-2}+0.193 \ln R G_{t-1}-0.658 \ln R G_{t-2} \\
\ln R I_{t}=0.184-0.001 t+0.112 \ln R C_{t-1}-0.087 \ln R C_{t-2}+0.573 \ln R I_{t-1}+0.188 \ln R I_{t-2} \\
+0.036 \ln R T_{t-1}-0.252 \ln R T_{t-2}+0.179 \ln R G_{t-1}+0.084 \ln R G_{t-2} \\
\ln R T_{t}=-0.163-0.001 t-0.054 \ln R C_{t-1}+0.069 \ln R C_{t-2}+0.171 \ln R I_{t-1}-0.256 \ln R I_{t-2} \\
+0.409 \ln R T_{t-1}+0.094 \ln R T_{t-2}+0.484 \ln R G_{t-1}-0.030 \ln R G_{t-2} \\
\ln R G_{t}=0.077-0.028 \ln R C_{t-1}+0.013 \ln R C_{t-2}+0.205 \ln R I_{t-1}-0.049 \ln R I_{t-2}+0.196 \ln R T_{t-1} \\
-0.179 \ln R T_{t-2}+0.608 \ln R G_{t-1}+0.170 \ln R G_{t-2}
\end{gathered}
$$

The Wald test results are reported in Table 4 . With statistical significance at the $5 \%$ level, there is Granger causality from the instant coffee price to the price of both coffee beans and green tea, meanwhile the green tea price Granger-causes the black tea price. 
Table 4. Results of LA-VAR tests between the luxury beverages' retail prices

\begin{tabular}{llrrrr}
\hline Dependent variables & Statistics & \multicolumn{3}{l}{ Independent variables } & \\
\cline { 3 - 6 } & & \multicolumn{1}{l}{$\ln (R C)$} & $\ln (R I)$ & $\ln (R T)$ & \multicolumn{1}{l}{$\ln (R G)$} \\
\hline $\ln (R C)$ & Wald statistics & $9.814^{*}$ & $5.223^{*}$ & 0.067 & 0.369 \\
& Probabilities & $0.000^{*}$ & $0.022^{*}$ & 0.796 & 0.544 \\
\hline $\ln (R I)$ & Wald statistics & 1.435 & $18.696^{*}$ & 0.048 & 0.427 \\
& Probabilities & 0.231 & $0.000^{*}$ & 0.827 & 0.514 \\
\hline $\ln (R T)$ & Wald statistics & 0.525 & 2.574 & $9.597^{*}$ & $4.839^{*}$ \\
& Probabilities & 0.469 & 0.109 & $0.002^{*}$ & $0.028^{*}$ \\
\hline $\ln (R G)$ & Wald statistics & 0.243 & $6.384^{*}$ & 3.814 & $13.167^{*}$ \\
& Probabilities & 0.622 & $0.012^{*}$ & 0.051 & $0.000^{*}$
\end{tabular}

Note: * denotes significance at the $5 \%$ level.

\section{Concluding Remarks}

This study examined the price formation of coffee beans in Japan, a country that is one of the largest coffee bean consumers in the world. This paper tested for Granger causality among ICO indicator prices, import prices, retail prices, and other luxury beverages' retail prices in order to determine the nature of information transmission between these economic variables. This study applied the LA-VAR technique developed by Toda and Yamamoto (1995) for these Granger-causality tests. Figure 3 shows the results of the analysis.

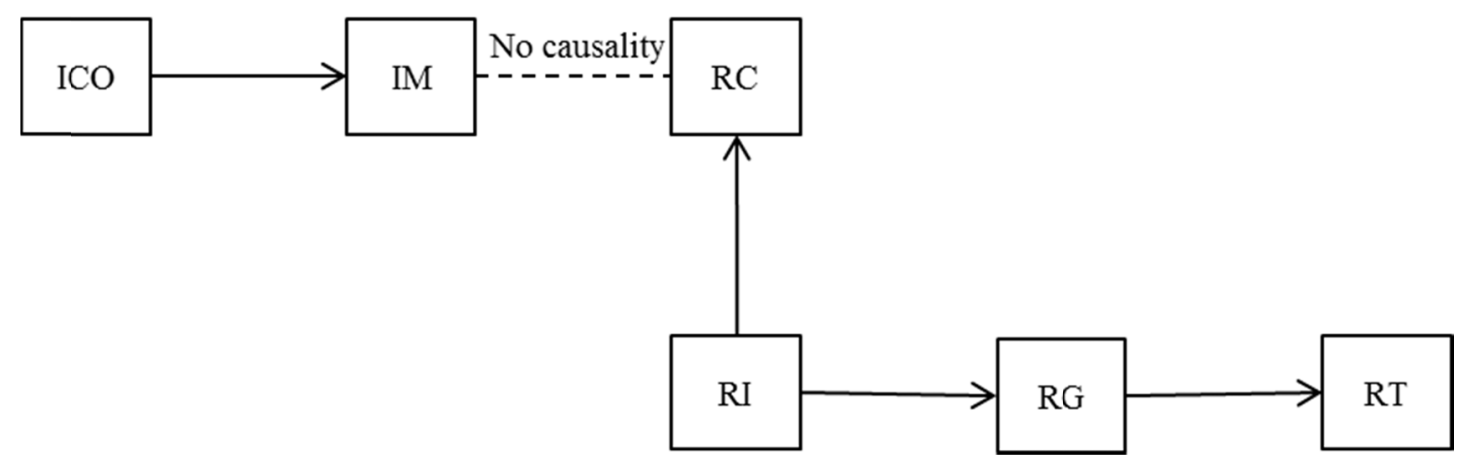

Figure 3. Results of Granger-causality tests

Granger causality from the international market price series to the import price series was found. This result shows that Japan has procured coffee beans at a price closely consistent with the international market price. Moreover, because the appropriate number of lag orders for estimating the VAR model is 3 , it may take about three months from a procurement agreement to clearance through customs. On the other hand, it was not observed that import prices affect international prices, even though Japan is one of the largest coffee consuming countries in the world. The reason for this is perhaps that although Japan's coffee consumption is high, it accounts only about $5 \%$ of the global consumption.

Granger causality between import prices and retail prices was not observed. This indicates that import price fluctuations are not directly passed onto the retail price. Therefore, it is possible for importers and/or retailers to make a considerable profit when the import price drops; however, it will be difficult to make a profit when the import price is increased. We can affirm that the volatility of their profits depends on the volatility of the international market price. Therefore, it can be concluded that the futures market is essential as their hedge against risk.

The Granger-causal relationships among the retail prices of luxury beverages are as described. The prices of instant coffee Granger-cause coffee bean and green tea prices. Meanwhile, green tea prices Granger-cause black tea prices. These results confirm that instant coffee is the only substitute good for coffee beans. Furthermore, it is possible that 
instant coffee can likely be the price maker for luxury beverages. In comparison to coffee beans, green tea, and black tea, instant coffee does not become stale easily and the storage costs are low. Therefore, it can be surmised that the prices of other luxury beverages will probably be adjusted in order to minimize the inventory, while a shipment of instant coffee would be adjusted in response to demand fluctuations.

In order to further develop this research in the future, an examination of price transmission, as conducted in this paper, will be required in other countries. Moreover, it would be interesting to investigate Granger causality between the economic variables considered in this research and other variables; for example, economic output, the price of futures in the commodity exchange, and retail prices of other potential substitute goods.

\section{References}

Delille, N. (2008). Relations between coffee world market price and retail price in Belgium, European Association of Agricultural Economists in its series 2008 International Congress, August 26-29, 2008, Ghent, Belgium, 43439.

Gómez, M. I., \& Koerner, J. (2009). Do retail coffee prices increase faster than they fall? Asymmetric price transmission in France, Germany and the United States. Cornell University Charles H. Dyson School of Applied Economics and Management, Working Papers 9-29.

Krivonos, E. (2004). The Impact of coffee market reforms on producer prices and price transmission. The World Bank, Policy Research, Working Paper Series 3358.

Lee, J., \& Gómez, M. I. (2013). Impacts of the end of the coffee export quota system on international-to-retail price transmission. Journal of Agricultural Economics, 64(2), 343-362. http://dx.doi.org/10.1111/j.1477-9552.2012.00372.x

Li, X., \& Saghaian, S. (2013a). An empirical analysis of coffee price transmission in Vietnam. Southern Agricultural Economics Association, 2013 annual meeting, Feburuary 2-5, 2013, Orlando, Florida.

Li, X., \& Saghaian, S. (2013b). An empirical comparison of coffee price transmission in Vietnam and Columbia. Agricultural \& Applied Economics Association, 2013 AAEA \& CAES Joint Annual Meeting, August 4-6, 2013, Washington, DC.

Maurice, N., \& Davis, J. (2011). Unravelling the underlying causes of price volatility in world coffee and cocoa commodity markets. Munich Personal RePEc Archive Paper 43813.

Mehta, A., \& Chavas, J. P. (2008). Responding to the coffee crisis: what can we learn from price dynamics? Journal of Development Economics, 85, 282-311. http://dx.doi.org/10.1016/j.jdeveco.2006.07.006

Toda, H. Y., \& Yamamoto, T. (1995). Statistical inference in vector autoregression with possibly integrated processes. Journal of Econometrics, 66, 225-250. http://dx.doi.org/10.1016/0304-4076(94)01616-8 